\title{
Microbiological Quality of Minas Artisanal Cheeses from Certified Properties at Serra da Canastra Region, Minas Gerais, Brazil in 2016
}

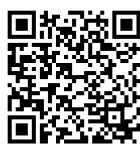

Felipe Machado de Sant'Anna ${ }^{1 *}$, Ihúna Luana Silva Carvalho ${ }^{2}$, Fernanda Silva Ferreira ${ }^{3}$ and Leonardo Borges Acurcio $^{2}$

${ }^{1}$ Departamento de Tecnologia e Inspeção de Produtos de Origem Animal, Escola de Veterinária, Brazil

${ }^{2}$ Centro Universitário de Formiga-MG (UNIFOR-MG), Formiga, Brazil

${ }^{3}$ Instituto Federal de Minas Gerais (IFMG), Bambuí, Brazil

Submission: February 03, 2018; Published: May 21, 2018

*Corresponding author: Felipe Machado de Sant’Anna, Universidade Federal de Minas Gerais, Campus Pampulha, Av. Antônio Carlos, 6627, 31270901, Belo Horizonte, MG, Brazil, Email: vetfelipem@gmail.com

Abstract

The aim of this study was to evaluate the conformity of minas artisanal cheese from certified properties of Medeiros city (Serra da Canastra region), from Minas Gerais state (Brazil), along the year of 2016. Most of the samples (approximately 75\%) presented permitted levels of pathogens or spoiling agents (coliforms at 30 and $45^{\circ} \mathrm{C}$, Listeria monocytogenes, Salmonella spp., and Staphylococcus aureus). Results show that there are still improvement to make but also show that the pressure from consumers, as well as from state agencies, for a cheese with better quality are starting to make a difference, since the results here presented are better than the latter results from older and similar studies.

Keywords: Microbiological; Maturation period; Tuberculosis; Brucellosis; Ripening periods; Lactic acid; Raw milk; Monocytogenes; Salmonella; Cheeses; Potabilty; Dairy farms; Fermentation; Lactose; Legislation; Coli forms.

\section{Introduction}

Minas Gerais State is the largest cheese producer in Brazil. Artisanal production of cheese made from raw milk, initially had a minimal ripening period of 60 days [1]. With the popularization of artisanal cheese, especially the ones from Serra da Canastra region, the state of Minas Gerais defined specific legislations in order to standardize the microbiological quality of these cheeses [2,3]. The main goal of these specific laws was to reduce the ripening period, since 60 days of maturation resulted in cheeses that did not attend to the sensorial profile which costumers of artisanal cheeses were used to. So, federal legislation determined that scientific studies were needed to determine which was the minimal maturation period of each cheese producing region [4]. State legislation accepted some of the studies rigorously produced and determined, for Serra da Canastra region, the minimal period of 22 days of ripening [5]. It is important to report that, among minimal ripening periods and microbiological qualities, other important characteristics were imposed by state and federal legislations, such as herd sanity (mandatory absence of tuberculosis and brucellosis, for e.g.) and good manufacturing practices (implementation of water potabilty, for e.g.).

\section{Material and Methods}

The agriculture institute from the State of Minas Gerais, located at Bambuí, analysed artisanal cheese from certified properties in order to evaluate if the maturation period of 22 days required at one of the main cities of the Serra da Canastra region (Medeiros) were enough to maintain cheese microbiological standard. Certified properties are the ones that attend all proper agricultural and manufacturer practices and are closely inspected by state organs, since they are only ones that can sell artisanal cheese to other Brazilian states [6].

In the year of 2016, 37 artisanal cheeses were analysed from certified properties at the region of Medeiros city. Samples were tested for coliforms that grow at 30 or $45{ }^{\circ} \mathrm{C}$, Staphylococcus aureus, Listeria monocytogenes and Salmonella spp. Permitted microbiological standards are shown at (Table 1).

\section{Results}

From April to December (2016), five (13.5\%) of the 37 cheese samples analysed presented counts of $S$. aureus above the limit allowed by state legislation (Table 1). Table 2 also shows that 
six $(14.2 \%)$ cheese samples were above the permitted limits for coli forms at $30^{\circ} \mathrm{C}$, as well as three $(8.1 \%)$ of them for coli forms at $45^{\circ} \mathrm{C}$. Fortunately, none of the 37 tested cheeses presented $\mathrm{L}$. monocytogenes or any type of Salmonella.

Table 1: Permitted microbiological standards for artisanal cheeses from Serra da Canastra region (Minas Gerais, Brazil).

\begin{tabular}{|c|c|}
\hline Microorganism & $\begin{array}{c}\text { Reference Value (Maximum } \\
\text { Accepted) }\end{array}$ \\
\hline Listeria monocytogenes & Absence in $25 \mathrm{~g}$ \\
\hline Salmonela spp. & Absence in $25 \mathrm{~g}$ \\
\hline Staphylococcusaureus & $1.0 \times 10^{3} \mathrm{CFU} / \mathrm{g}$ \\
\hline Coliforms at $35^{\circ} \mathrm{C}$ & $5.0 \times 10^{3} \mathrm{CFU} / \mathrm{g}$ \\
\hline Coliforms at $45^{\circ} \mathrm{C}$ & $5.0 \times 10^{2} \mathrm{CFU} / \mathrm{g}$ \\
\hline
\end{tabular}

Table 2: Conformity (\%) for pathogen and spoiling agents evaluated from 37 artisanal cheeses from Medeiros city (Serra da Canastra region) from April to December (2016).

\begin{tabular}{|c|c|}
\hline Microorganism & $\begin{array}{c}\text { Samples above accepted limit } \\
\text { (\%) }\end{array}$ \\
\hline Listeria monocytogenes & $0(0)$ \\
\hline Salmonela spp. & $0(0)$ \\
\hline Staphylococcusaureus & $5(13.5)$ \\
\hline Coliforms at $35^{\circ} \mathrm{C}$ & $6(14.2)$ \\
\hline Coliforms at $45^{\circ} \mathrm{C}$ & $3(8.1)$ \\
\hline
\end{tabular}

\section{Discussion}

Most of the undesirable microorganisms found come from poor hygiene of the utensils used in milking and/or cheesemaking. Dores et al. [7] showed that 22 days of ripening are sufficient to eliminate $S$. aureus from artisanal cheeses from Serra da Caanstra region. The reduction observed in this study shows the confirmation of this scenario, in which cheese makers are improving their processes, demonstrating that they are gaining conscience of the importance of a clean and hygienic process. S. aureus commonly come either from cheese makers or from mastitis cows, as discussed by Lim et al. [8], who found high percentages of $S$. aureus (including antibiotic resistant strains) in all environments, workers and animals from dairy farms.

Regarding Salmonella spp. and Listeria monocytogenes, which are the most concerning pathogenic agents involved in food poisoning [9]. In that manner, it is interesting to notice the absence of these concerning pathogens in artisanal cheeses. Martins et al. [10] observed that 22 days of ripening are sufficient to inhibit these genera of microorganisms. These authors attributed the reduction of undesirable microorganisms along ripening to the reduction of $\mathrm{pH}$ (mainly due to organic acid production by lactic acid bacteria from raw milk) and to the reduction of humidity that naturally occurs, reducing water activity (Aw) and consequently the conditions that allows microorganism to multiply.

Coliforms are especially associated with early swelling of cheese (caused by gas production through fermentation of lactose), compromising its quality and making its sale unfeasible.
Castro et al. [11] observed, as it was observed in this research, that the presence of this group of microorganisms are usually related to rainy seasons (represented by the months of December and January in Minas Gerais). This is due to the mud formed that carries more coliforms via cheese makers clothing and/or cows udder.

\section{Conclusion}

Artisanal cheeses from certified properties located at Serra da Canastra region, from Medeiros city, showed, throughout the year of 2016, a reasonable microbiological quality. The results show that there are still some improvements to make but also show that the market pressures, as well as pressure from state agencies, for a cheese with better quality are starting to make a difference, since the results here presented are better than the latter results from older and similar studies.

\section{Conflict of interest}

The authors declare that they have no competing interests.

\section{Acknowledgment}

We thank Instituto Mineiro de Agropecuária (IMA) for providing the data that made this study possible.

\section{References}

1. Brasil (1996) Portaria 146 (07/03/1996): Aprova os Regulamentos Técnicos de Identidade e Qualidade dos Produtos Lácteos. Ministério da Agricultura, Pecuária e Abastecimento, Brazil.

2. Minas Gerais (2002) Decreto 42.645 (05/06/2002): Dispõe sobre o processo de produção de queijo Minas artesanal, Assembleia Legislativa do Estado de Minas Gerais, Belo Horizonte, Brazil.

3. Minas Gerais (2008) Decreto 44.864 (01/08/2008): Altera o regulamento da lei $\mathrm{n}^{\circ} 14.185$ de 31 de janeiro de, que dispõe sobre o processo de produção do queijo de minas artesanal. Assembleia Legislativa do Estado de Minas Gerais, Belo Horizonte, Brazil.

4. Brasil (2011) Instrução Normativa 57 (15/12/2011): critérios adicionais para elaboração de queijos artesanais. Ministério da Agricultura, Pecuária e Abastecimento, Brazil.

5. Minas Gerais (2017) Portaria 1.736 (27/07/2017): altera a Portaria ${ }^{\circ}$ 1305/2013, de 30 de abril de, que dispõe sobre o período de maturação do Queijo Minas Artesanal. Assembleia Legislativa do Estado de Minas Gerais, Brazil.

6. Minas Gerais (2012) Lei 20.549 (18/12/2012):dispõe sobre a produção e a comercialização dos queijos artesanais de Minas Gerais. Assembleia Legislativa do Estado de Minas Gerais, Belo Horizonte, Brazil.

7. Dores MT, Nóbrega JE, Ferreira CLLF (2013) Ripening at room temperature warrants microbiological safety in the Brazilian Artisan Canastra Cheese. Food Sci Technol 33: 180-185.

8. Lim SK, Nam HM, Jang GC, Lee HS, Jung SC, et al. (2013) Transmission and persistence of methicillin-resistant Staphylococcus aureus in milk, environment, and workers in dairy cattle farms. Foodborne Pathog Dis 10(8): 731-736.

9. Crim SM, Griffin PM, Tauxe R, Marder EP, Gilliss D et al. (2015) Preliminary Incidence and Trends of Infection with Pathogens Transmitted Commonly Through Food - Foodborne Diseases Active Surveillance Network, 10 U.S. Sites, 2006-2014. MMWR Morb Mortal Wkly Rep 18: 495-499. 
10. Martins JM, Galinari E, Pimentel-Filho NJ, Ribeiro Junior JI, Furtado MM et al. (2015) Determining the minimum ripening time of artisanal Minas cheese, a traditional Brazilian cheese. Braz J Microbiol 46: 219230
11. Castro RD, Oliveira LG, Sant'Anna FM, Luiz LMP, Sandes SHC, et al. (2016) Lactic acid microbiota identification in water raw milk endogenous starter culture and fresh Minas artisanal cheese from the Campo das Vertentes region of Brazil during the dry and rainy seasons. J Dairy Sci 99(8): 6086-6096.

\section{Your next submission with Juniper Publishers will reach you the below assets}

- Quality Editorial service

- Swift Peer Review

- Reprints availability

- E-prints Service

- Manuscript Podcast for convenient understanding

- Global attainment for your research

- Manuscript accessibility in different formats ( Pdf, E-pub, Full Text, Audio)

- Unceasing customer service

Track the below URL for one-step submission https://juniperpublishers.com/online-submission.php 